\title{
The Role of The Humanitarian Action International Committee for The Red Cross (ICRC) in The 2011 Libya Revolution
}

\author{
Fitri Adi Setyorini \\ Universitas Muhammadiyah Yogyakarta \\ Email: fitrisetyorini16@gmail.com
}

\begin{abstract}
This study discusses the International Committee for the Red Cross (ICRC) role in protecting and assisting victims of the Libyan revolution in 2011. The purpose of this study is to explore more about the role of the International Committee for the Red Cross (ICRC) in protecting and assisting victims of war as one step on a humanitarian mission. The author used the non-government organizations (NGOs) and humanitarian action concepts. The author's research method to analyze this study was a descriptive method through a literature review. Based on research done, the author found that the revolution in Libya in 2011 was one of the effects of the Arab Spring in the Middle East region. The author also found that the ICRC carried out its humanitarian missions by providing food, water, medical supplies, medical equipment, and clothing.
\end{abstract}

Keywords: Libya, ICRC, Humanitarian Action, Arab Spring

\begin{abstract}
Abstrak
Penelitian ini membahas tentang peran International Committee for the Red Cross (ICRC) dalam melindungi dan membantu korban revolusi Libya pada tahun 2011. Tujuan dari penelitian ini adalah untuk mengetahui peran International Committee for the Red Cross (ICRC) dalam melindungi dan membantu korban perang sebagai salah satu langkah dalam misi kemanusiaan. Penulis menggunakan konsep non-government organization (NGO) dan konsep humanitarian action untuk menganalisis peran humanitarian action ICRC dalam revolusi Libya tahun 2011. Metode
\end{abstract}


penelitian yang digunakan oleh penulis untuk menganalisis penelitian ini adalah metode deskriptif melalui kajian kepustakaan. Berdasarkan penelitian yang telah dilakukan, penulis menemukan bahwa revolusi yang terjadi di Libya pada tahun 2011 merupakan salah satu efek dari Arab Spring yang terjadi di wilayah Timur Tengah. Selain itu, penulis juga menemukan bahwa ICRC menjalankan peranannya dalam misi kemanusiaan melalui pemberian bantuan makanan, air, obat-obatan, alat medis, pakaian dan lain sebagainya.

Kata kunci: Libya, ICRC, Humanitarian Action, Arab Spring

\section{INTRODUCTION}

Conflict in international relations has increased along with the movement of democracy and freedom waves, leading to protests to bring down authoritarianism and injustice in several Middle East regions, called the Arab Spring (Sahide, 2015, hal. 118). The Arab Spring was started in Tunisia in December 2010 when a young man named Bouazizi did self-immolation as a protest that succeeded in overthrowing Zainal Abidin Ben Ali (Ghafur, 2014, hal. 86). The protests then spread to the Middle East, and one that took place in Tahrir Square, Egypt, on January 25, 2011, also succeeded in overthrowing Husni Mubarok (Ghafur, 2014, hal. 86).

The protests in Tunisia and Egypt resulted in a change in Libya's political climate, leading to a resistance movement in Benghazi to overthrow Muammar Gaddafi in February 2011 (Nainggolan, 2019, hal. 7). The supports to overthrow Muammar Gaddafi's 40-year regime was getting more powerful when the Security Council of the United Nations (UN) and the North Atlantic Treaty Organization (NATO) joined under Humanitarian Intervention to protect Libyan civilians' safety following UN Security Council Resolution 1973 (Nur, 2015) (Sahide, 2015, hal. 118). Muammar Gaddafi was killed in an attack launched by an insurgent group in Sirte on October 20, 2011 (Gunawan, 2014).

The Arab Spring, as the beginning of the awakening of new hopes for a better and democratic life, especially in the Middle East, gave birth to a more tense and frightening atmosphere because overthrowing an authoritarian regime involved rather violent 
elements. Even after eight years after Muammar Gaddafi's government was successfully overthrown, Libya still experiences armed conflicts between militia groups, the military, and pro-regime groups from the past (Nainggolan, 2019, hal. 7). This prolonged armed conflict in Libya has killed thousands of people. According to the Libyan Health Minister under the leadership of the National Transitional Council (NTC), Naji Barakat stated that during the six months of overthrowing Muammar Gaddafi, around 30,000 people were killed and 50,000 people were injured (Nugraha, 2011). According to the World Health Organization (WHO), from April to July 6, 2019, the death toll from Libya's conflict reached 1,000 (Perdana, 2019). Until now, the Security Council of the United Nations (UN) is still trying to urge the parties to the conflict to agree to a ceasefire, considering that tens of thousands of victims from the ferocious armed upheaval in Libya.

The Arab Spring is hoped to be the solution to a better and democratic life. However, the steps taken through acts of resistance and rebellion have had lasting consequences. Armed conflict on upholding democracy causes many losses, including women and children who should be protected from the attacks.

Children are the easiest target for opposition groups and the old pro-regime groups to become soldiers (Child Soldier) (I Gede Adhi Supradnyana, 2020). No child dreams and aspires to spend his childhood guerrillas in the forest, carry firearms and hunt targets using a shouldered weapon. However, around 300,000 children were trapped in this situation (Sinaga, 2010). Director of the United Nations Children's Fund (UNICEF) for the Middle East and North Africa, Geert Cappelaere, stated that around 500,000 children had been recruited into child soldiers in Libya (Perdana, 2018).

Parents and mothers are also easy targets. The threat to the lives and safety of civilians causes a high wave of refugees. The armed conflict in Libya led to a wave of refugees from Libya heading to neighboring countries, such as Tunisia and Egypt, where 100,000 people entered Tunisia to avoid conflict in their country (ICRC, Sejarah, 2019).

The International Committee of the Red Cross (ICRC), as an international non-governmental organization, strives to protect and assist victims of conflict and armed upheaval. The civil war in Libya 
that lasted for nine years (2011 to 2020) due to the Arab Spring wave has killed hundreds of thousands of people and threatens their safety, especially children and women protected under the 1949 Geneva Convention. Besides, the continuing conflict has resulted in an increased number of refugees from Libya.

The ICRC provides protection and humanitarian assistance directly on the battlefield through a series of actions in the health sector and meeting primary needs for the victims (ICRC, History, 2019). Their role is an exciting issue to research. Even though Libya's conflict was a step towards a democratic process, the civilians' safety also needed to be considered to continue their lives again.

\section{RESEARCH METHOD}

The author used qualitative research methods that focused on literature review and read works related to the International Committee of the Red Cross (ICRC) to ensure protection and assistance for conflict and armed upheaval victims in Libya. The author chose Libya due to its 9-year conflict, which had killed thousands of lives and caused a high wave of refugees in several neighboring countries, such as Tunisia and Egypt.
Other sources in this paper were articles, news, journals that provided supporting data to understand the International Committee of the Red Cross (ICRC) in ensuring protection and assistance for victims of conflict and armed upheaval in Libya. The author conducted a literature review first regarding the chronology of the emergence of conflict turmoil and its development in Libya.

\section{Theoretical Framework}

The author used two concepts to analyze the issue, called the NonGovernment Organization (NGO) and Humanitarian Action.

\section{Non-Government Organization (NGO) Concept}

Non-governmental organizations (NGOs) are one of the actors in international relations since the 19th century. According to Margaret P. Karns, a nongovernmental organization (NGO) is defined as a group of individuals or voluntary organizations, usually not affiliated with any government to provide services or advocate for public policy. Meanwhile, according to Tujil, NGOs can be defined as independent, non-partisan, nonprofit organizations aiming to improve the marginalized quality (Tujil, 1999). 
According to David Lewis in a book entitled The Management of Non-Governmental Development Organization, one way to analyze NGOs' role is from an organizational perspective. Three points can explain NGOs' fundamental role. David Lewis distinguishes NGOs' roles into three types: implementers, catalysts, and partners (Lewis, 2007).

This research used the NGO paradigm proposed by Mansour Fakih about the NGO paradigm typology. This typology classifies NGOs according to paradigm, action and structure. This typology describes the NGO movement in three types: the paradigm of conformism, reform and transformation (Fakih, NGOs in Indonesia, 1991).

Fakih mapped the political positions of NGO activists into three types. First, the conformist consists of NGO activists who carry out their work based on the charitable aid paradigm, or what is often called "working without theory," or are project-oriented and work as charitable aid organizations. This type adapts itself to the existing system and structure. Their programs and activities' primary motivations to help the people in need (Fakih, 1991).
The second category is reformers. This type of NGO is based on the ideology of modernization and developmentalism. Public participation in development needs to increase by placing corruption issues in the government as the leading cause of society's backwardness (Fakih, 1991). They pay more attention to aspects of the approach and methodology in their movements and support developmentalism. This view's main objective is to change the top-down and non-participatory approach to an approach that emphasizes participation and community selfhelp (Ningrum, 2010).

Third, the transformation perspective consists of NGO groups that re-examine basic assumptions and ideological problems to find an alternative to the other two approaches. One of these perspectives is to question the mainstream paradigm and ideology hidden in it and to try to find alternative paradigms that will change the structures and supra structures that oppress the people and the possibility of unlocking their human potential (Fakih, 1991). This paradigm makes it possible for the people to control the production of information and their ideology. This approach is usually 
found among NGOs working on environmental issues and clearly shows the spirit of counter-capitalist hegemony through its newspapers and magazines. It is translated through their campaign and advocacy programs to defend and support poor farmers, indigenous people, and marginalized groups (Fakih, 2004).

\section{Humanitarian Action Concept}

Humanitarian action is carried out by individuals or groups where aspects of humanity are being threatened, such as natural disasters, conflicts, or wars. This humanitarian action aims to save human life. Humanitarian action is based on four basic principles, such as (Karmila, 2018)

a. Humanity

Humanitarian action is purely to help and protect people from their suffering.

b. Impartial

Humanitarian action is carried out without any discrimination in any form or on any basis.

c. Independence

Humanitarian action stands alone or is separate from autonomy and military, political and economic interests.

\section{d. Neutrality}

Humanitarian action is neutral or does not take sides with any party.

Humanitarian action helps and protects civilians, wounded soldiers, children victims of war by providing food, proper water sanitation, temporary shelter, health services and education. 'Humanitarian Aids' is distributed by the state, individuals, groups, domestic/international companies, Non-Government Organizations (NGOs), or International Government Organizations (IGO). Meanwhile, workers from domestic/ international organizations and humanitarian goals are called 'Humanitarian Workers/Aid Workers/Humanitarian Aid Workers.

Humanitarian workers are much protected and respected. Humanitarian workers work in nonarmed conflict situations. Then, they are covered by International Human Rights Law and domestic legislation. However, if the humanitarian worker works in an armed conflict situation, they will be protected by international humanitarian law (Karmila, 2018). 


\section{DISCUSSION}

\section{Dynamics of Conflict in Libya}

Sociologically, conflict is defined as a social process between two or more people or groups in which one party tries to get rid of the other by destroying or rendering the opponent powerless (Sofiyati, 2011, hal. 2). Meanwhile, according to Winardi, conflict is the opposition or a disagreement between people, groups and organizations (Winardi, 1994, hal. 1).

There are two different views on seeing conflict. The traditional view considers that conflict is a harmful action and must be avoided. According to the modern view, conflict is a good action and must continue to be developed because it can stimulate problemsolving (Sotopo, 2012, hal. 267). The dynamics of Libya's conflict have been rolling for approximately nine years (2011 to 2020). The conflict was the result of the Arab Spring. The author will analyze the dynamics of the conflict in Libya using the conflict stages based on periods. The following is a picture of the stages of conflict escalation.

\section{Figure 1. Conflict Stages}

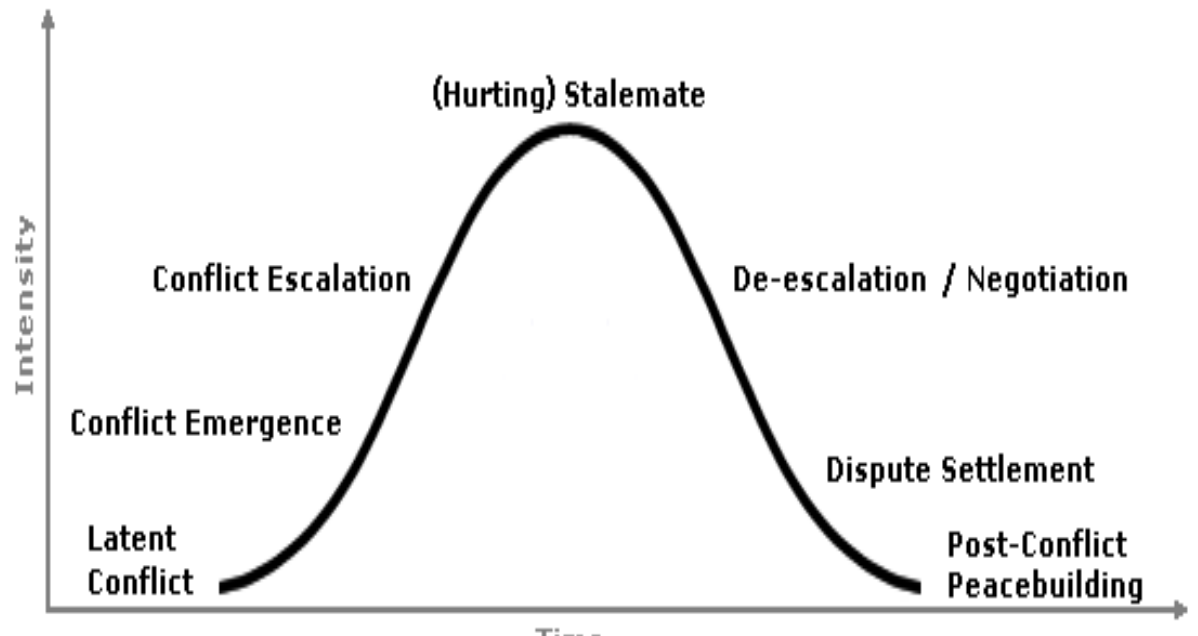

Time

Source: (Brahm, 2003)

Based on the figure above, the author analyzes the chronology of Libya's conflicts for nine years (2011 to 2020). 


\section{1) Pre-conflict}

Pre-conflict is a condition when a mismatch of goals between two or more parties happen. Libya was once led by an authoritarian leader named Muammar Gaddafi. His regime lasted for 40 years. Muammar Gaddafi started his regime after his coup d'etat against King Idris on September 1, 1969. In April 1973, Muammar Gaddafi carried out a cultural revolution by issuing a ban on communism, conservatism, capitalism, atheists, and other Muslim groups (Syahputra, 2017). This act violated fundamental human rights, which was the freedom to determine someone's beliefs and activities. Gaddafi also eliminated political parties and considered people involved in political parties as a traitor.

Muammar Gaddafi nationalized all businesses and determined that all economic activities were under state control. In 2006, there was a demonstration against hanging a human rights activist in Libya (Akbar, 2015). However, Libya's turmoil again subsided because the authoritarian policies imposed by Muammar Gaddafi were seen as commonplace. Until finally, the Libyan people realized the Arab Spring in 2010, which became a new hope for the Middle East people to get a more democratic life.

The Arab Spring started in Tunisia in December 2010 when a young man named Bouazizi did self-immolation as a protest that succeeded in overthrowing Zainal Abidin Ben Ali (Ghafur, 2014, hal.86). The widespread protests in the Middle East also succeeded in overthrowing Husni Mubarok in Egypt (Ghafur, 2014, p. 86).

Muammar Gaddafi realized that the Arab Spring phenomenon could spread to Libya. Therefore, Gaddafi issued a policy to block social networks, which triggered heated relations between legitimate government groups and opposition groups who wanted to overthrow him (Syahputra, 2017).

\section{2) Confrontation}

Confrontation happens when conflict grows wider. In the dynamics of the Libyan conflict, it began with an anti-government demonstration on February 15, 2011. This demonstration was held by approximately 600 people in front of the Benghazi police headquarters (Agustinova, 2013). The demonstration was triggered by the arrest of a human rights activist, Fathi Terbil. Demonstrations were increasingly being held in various 
parts of Libya, such as Tajoura, Zintan, Ajdabiyah, Al Bayda, Tripoli, and Misrata (Syahputra, 2017).

The demonstration ended chaotically after Gaddafi's party sent mercenaries who opened fire on the demonstrators using helicopters. The victims reached 300 people from opposition groups and 120 people from the pro-Gaddafi forces (Agustinova, 2013). At this stage, various kinds of attacks and violence were committed by both parties to the conflict. Since February 21, 2011, Gaddafi's troops increasingly deployed their warplanes to bombard demonstrators in Tripoli (Agustinova, 2013).

The confrontation stage was also marked by both parties' activities, which gathered support and assistance from outside parties. Muammar Gaddafi's party garnered support from his loyal followers, including Libyan Prime Minister Baghdadi al-Mahmudi. He also brought mercenaries from Niger and Chad to bombard alleged traitors (Akbar, 2015).

\section{3) Crisis}

A crisis is often referred to as the peak of the conflict. At this stage, the relationship between the two warring parties is in tension. Muammar Gaddafi's forces controlled Tripoli, while antigovernment opposition groups controlled western Libya, such as Benghazi, Misrata, and Ajdabiya (Agustinova, 2013). Muammar Gaddafi's actions were increasingly brutal and uncontrollable. Until finally, at the end of February 2011, the opposition group formed the National Transitional Council of Libya (NTC) as a rival government to overthrow Gaddafi's regime (Agustinova, 2013).

On March 8, 2011, Muammar Gaddafi's troops attacked Zawiya in response to a statement made by the opposition leader, Mustafa Abdul Jalil (Syahputra, 2017). The opposition leader stated that they would not pursue Gaddafi if he were willing to step down from his chair within 72 hours from March 7, 2011. The attack carried out by Gaddafi's group made western Libya fall into the hands of pro-Gaddafi and further cornered the position of the opposition group.

The brutal actions carried out by Gaddafi's loyalist group drew a response from the international community. On March 17, 2011, the United Nations, as an international organization, passed a resolution to implement a "no-fly zone" to Libya, prohibiting the shipment of weapons to and from Libya, and issued an 
order to freeze the assets of the Gaddafi family abroad (Agustinova, 2013). Most North Atlantic Treaty Organization (NATO) members began to prepare sea and air troops to Libya as a follow-up to the United Nations' resolution. The actions taken by NATO member countries were based on humanitarian intervention actions to protect Libyan civilians' lives.

On March 19, 2011, France sent dozens of troops and warplanes to Libya to destroy heavy vehicles and air defense bases belonging to Gaddafi's loyalist forces. The French action was followed by Britain, the United States, ten member countries of the North Atlantic Treaty Organization (NATO), and some Arab countries. Apart from sending troops and warplanes, these countries also sent weapons, money and military training for opposition forces (Syahputra, 2017).

The fighting between the opposition group and Gaddafi's loyalist group was heating up until it peaked on August 20, 2011, in Tripoli. The Libyan capital was inundated by Gaddafi's loyalists firing on from the top of the buildings' water towers and roofs. Opposition groups managed to seize Tripoli from Gaddafi's loyalist group at the end of August 2011. The war spread to Sirte, Gaddafi's birthplace, suspected as Gaddafi's hiding place (Akbar, 2015).

\section{4) Consequences}

A consequence affects the conflicting parties, the wider community, and the environment. The war spread to Sirte, which managed to fall into the opposition's hands. On the same date, Muammar Gaddafi had fled out of Sirte with his bodyguards by car. Gaddafi's action was responded to by the North Atlantic Treaty Organization (NATO) air force which then fired on Gaddafi's motorcade. Muammar Gaddafi managed to survive the attack launched by the North Atlantic Treaty Organization (NATO), then he hid under a sewer (Agustinova, 2013).

Opposition groups found out where Muammar Gaddafi was hiding, and they dragged him out of the sewer. Muammar Gaddafi was then surrounded and shot in the head, and people displayed his body at a butcher shop in Misrata. The fourth stage in the conflict analysis stage is marked by victory, defeat, ceasefire, control, and control. The battle between opposition groups and Gaddafi's loyalists for nine months (February to October 2011) was won by the opposition group 
led by the National Transitional Council of Libya (NTC). The end of the war in Libya was followed by the North Atlantic Treaty Organization (NATO) decision to stop all military operations by the end of October 2011 (Akbar, 2015).

\section{5) Aftermath}

Aftermath or post-conflict is when violence and tension are slowly reducing and returning to a normal situation. The Libyan civil war that lasted for nine months (February to October 2011) resulted in thousands of deaths. The death toll was approximately 10,000 - 40,000 people, where most of the victims killed were civilians, including women, the elderly, and children. The war in Libya also resulted in refugees coming from Libya to Tunisia and Egypt (Akbar, 2015).

After the civil war ended, the National Transitional Council of Libya (NTC), which won the battle, made several Libya changes to the Libyan government system, wherein the Muammar Gaddafi government's era used the socialist "Arab Jamahiriya" government system. It was then abolished and replaced with a republican system of government. In the military field, the National Transitional Council of
Libya (NTC) made changes from the NTC military to the Libyan national army (Ardiansyah, 2014).

At the final stage of the conflict analysis, if the remaining issues or problems from this conflict are not resolved immediately, it can trigger the pre-conflict stage again. Muammar Gaddafi was shot dead, and the opposition won the battle. However, new problems emerged along with the changes made by the NTC. The reason is, the NTC was formed from various groups with anti-Gaddafi ties. After Gaddafi died, divisions within the NTC began to grow.

Since the Libyan civil war ended, small-scale armed conflicts have continued. These conflicts occurred between remnants of Gaddafi's loyalist groups and groups within the NTC. There have also been conflicts between ethnic groups and local armed groups (nine years), allowing weapons to circulate freely (Ardiansyah, 2014).

\section{ICRC as International Humani- tarian Actor}

Jean Henry Dunant established the International Committee of the Red Cross (ICRC). It is an independent non-governmental organization and neutral on political, religious and ideological issues. 
This institution is the Red Cross and Red Crescent Movement's first organization, with its headquarters in Geneva, Switzerland. The ICRC has approximately 15 to 25 members who are Swiss nationals elected by mutual decision (ICRC, 1996, p. 12). ICRC membership is regulated in Article 7 of the ICRC Statute, which only recruits members from Swiss due to its neutrality, hoping to become an independent intermediary institution in mediating an armed conflict (ICRC, 1996, hal. 2).

If only seen from its membership composition, ICRC is not an international organization because it severely limits its membership to Swiss nationals. However, the ICRC is seen as an international non-governmental organization when viewed from its humanitarian missions worldwide. This organization's mission is solely humanitarian to assist and protect the lives and dignity of victims of war and domestic violence (ICRC, 2005, hal. 1).

ICRC's primary duties are to prevent and alleviate human suffering without discrimination and protect human dignity. In carrying out its activities, the ICRC has the basic principles set out in the 20th International Conference of the Red Cross, and Red Crescent held in Vienna, 1965 (ICRC, 1996, hal. 4) :

\section{a. Humanity}

ICRC aims for humanitarian actions, such as helping and protecting victims of war without discrimination, preventing and alleviating war victims worldwide.

b. Impartiality

ICRC does not see race, religion, status, ethnicity and political views. However, it will treat victims differently depending on their state of health and injuries. In terms of humanity, the prohibition of acts of non-discrimination has been regulated in the Geneva Convention 1949 Article 3 Paragraph 1.

c. Neutrality

ICRC as an organization is not allowed to take sides and involve itself in all matters relating to politics, race, religion and ideology. Besides, ICRC is prohibited from taking any action that could cause more casualties from the conflict parties.

d. Independence

ICRC provides medical services to assist local governments 
and comply with existing regulations in each country. However, ICRC must still refuse any interference or intervention from a political, ideological, racial, religious and economic nature to maintain its Independence.

e. Voluntary Service

ICRC works without seeking any profit. The nature of this organization is volunteerism that upholds the human aspect.

f. Unity

National Red Cross aims to help each country's government form a national association engaged in humanitarian affairs and integrate the branches and the center.

g. Universality

Based on the universality principle, ICRC is recognized throughout the world. With this principle, this institution can provide services and protection to humanity around the world.

\section{ICRC's Role in Humanitarian} Action to Protect Victims of the Libyan Revolution in 2011

The Libyan civil war was the long-term impact of the Arab Spring in the Middle East, especially in Tunisia and Egypt. The civil war in Libya from February to October
2011 caused various kinds of losses. The death toll was approximately 10,000 - 40,000 people, where most of the victims killed were civilians, including women, the elderly, and children. The war also resulted in refugees to countries around Libya, such as Tunisia and Egypt (Akbar, 2015).

The increasing casualties and the influx of Libyan refugees to Tunisia and Egypt sparked various international community responses. One of them was the response given by the International Committee of the Red Cross (ICRC) as a nongovernmental organization with a humanitarian mission. The primary mission of the ICRC is to assist and protect the lives and dignity of victims and violence at home or abroad without discrimination. ICRC is protected by International Humanitarian Law and the Geneva Conventions of 1969.

According to the ICRC President, Jacob Kellenberger, in 2011, spent approximately Rp. 11.3 Trillion to provide humanitarian assistance in 80 countries, including Libya (ICRC, 2012). The following are some of the roles of the ICRC's humanitarian actions to assist and protect victims of the Libyan Civil War, which culminated in September-October 2011. 
a. In September 2011, the ICRC helped reunite separated families through the transfer of people between Tripoli and Benghazi and between Benghazi and Tripoli. These people were separated from their families in January 2011 due to the Civil War (ICRC, 2011).

b. Civil War in Sirte, Libya, led to an increasing influx of refugees. The refugees stated that the stock of medicines, food, water, health access was minimal. The refugees began to catch fever and diarrhea because they did not have access to toilets. The refugees fled from Sirte to the desert between the cities of Sirte and Harawa. On September 26, 2011, the ICRC provided humanitarian assistance consisting of water and hygiene kits to approximately 7,800 refugees and 57,000 baby food bottles. It also distributed hygiene kits, diapers, food, water and kitchen utensils to approximately 859 refugees in Misrata and Tamina and 700 refugees in Wadi Mara (ICRC, 2011).

c. Civil War in Libya caused a wave of refugees inside Libya and spread to Tunisia. It mainly

caused water resources in the border of Southeast Tunisia to become increasingly depleted. In September 2011, ICRC collaborated with the Tunisian National Water Management Agency to build 15.5 kilometers of water pipelines to connect wells with water reservoirs for 100,000 refugees in Ben Guerdane and Ramada (ICRC, 2011).

d. Apart from constructing a water pipeline and medical assistance, ICRC also deployed two of its forensic experts to help Libyans identify mass buried bodies and help Libyans find their families who have been reported missing since the civil war broke out (ICRC, 2012).

e. On October 3, 2011, ICRC, led by a doctor named Hichem Khadraoui, managed to break through Sirte, pro-Gaddafi groups and conflicting opposition. He stated that an increasing number of injured victims were being admitted to the Ibn Sina Hospital in Sirte. The situation was exacerbated by the depletion of medical equipment and oxygen and damaged water reservoirs. ICRC team successfully provided surgical equipment 
for more than 200 wounded victims, bandages, body bags, and 400 liters of fuel to run hospital generators (ICRC, 2011).

f. On October 7, 2011, ICRC officers successfully evacuated three critical patients, 17 patients on October 11, 2011, and 21 patients on October 17, 2011, to be transferred from Ibn Sina Hospital to Misrata. In October 2011, 58 patients were successfully evacuated. Three patients needed intensive care, while doctors in Sirte City were decreasing due to the closure and blocking of access roads leading to Sirte. The evacuation could only be done when the opposition group and the pro-Gaddafi group agreed on a ceasefire for several hours (ICRC, 2011).

g. ICRC made visits to 50 places of detention in Libya, more than 6,000 detainees in Tripoli and 2,500 detainees in Misrata. One thousand five hundred detainees were foreign nationals from sub-Saharan Africa. The purpose of conducting these visits was to monitor the shelters. It also provided detainees opportunities to contact their families, clothing, sheets, mattresses, buckets and toiletries for detainees (ICRC, 2011).

h. In October 2011, ICRC provided humanitarian assistance to more than 30,000 Libyan refugees in Libya. The humanitarian aid consisted of clothes, water, food, diapers, hygiene kits, baby food, and milk (ICRC, 2011).

Providing humanitarian in Libya done by ICRC is challenging because humanitarian fighters are targets of armed groups. Indeed, the volunteers are supposed to save other humans' lives. Ambulances, medical personnel, medical facilities must be respected and protected by all parties. Benghazi and Misrata's ICRC headquarters experienced five armed attacks in the past three months (ICRC, 2012).

The armed attacks continued and were directed directly to the ICRC headquarters in Libya. The ICRC team urged the Libyan government to make a memorandum of understanding. On June 26, 2012, ICRC and the Libyan Armed Forces signed a memorandum of understanding, under which ICRC would assist and support integrating the rules of International Humanitarian Law into the training and operations of 
the Libyan Armed Forces and in the Libyan Military Law, considering Libya was a party to the Geneva Conventions and Additional Protocols I and II (ICRC, 2012). The signing of this memorandum of understanding is the first step for Libya to ensure International Humanitarian Law in Libya.

\section{CONCLUSION}

Libyan Revolution is the longterm impact of the Arab Spring in the Middle East region. The revolution that occurred in 2011 led to the outbreak of civil war from February to October 2011 and caused various kinds of losses. The Libyan Civil War's death toll was approximately 10,000 - 40,000 people, where most of the victims killed were civilians, including women, the elderly, and children. The war in Libya also resulted in refugees coming from Libya to countries around Libya, such as Tunisia and Egypt.

The increasing casualties and the influx of Libyan refugees to Tunisia and Egypt sparked various international community responses. One of them was the response given by the International Committee of the Red Cross (ICRC) as a nongovernmental organization with a humanitarian mission. The primary mission of the ICRC is to assist and protect the lives and dignity of victims and violence at home or abroad without discrimination. The ICRC provides assistance and protection as follows:

1. Uniting separated families by transferring people between Tripoli and Benghazi and between Benghazi and Tripoli

2. Providing humanitarian assistance consisting of water, 57,000 bottles of baby food and hygiene kits to approximately 7,800 refugees, 859 refugees in Misrata and Tamina, and 700 refugees in Wadi Mara (ICRC, 2011)

3. Working with the Tunisian National Water Management Agency to build 15.5 kilometers of water pipelines to connect wells with water reservoirs for 100,000 refugees in Ben Guerdane and Ramada

4. Deploying two forensic experts to assist Libyans in identifying mass buried bodies

5. Assisting surgical equipment for the home of more than 200 wounded victims, bandages, body bags, and 400 liters of fuel to run the hospital's generator

6. Evacuating three critical patients on October 7, 2011, 17 patients on October 11, 2011, 
and 21 patients on October 17, 2011, transferred from Ibn Sina Hospital in Sirte to Misrata

7. Visiting more than 6,000 detainees in Tripoli and 2,500 detainees in Misrata to monitor the treatment given to the shelter.

\section{BIBLIOGRAPHY}

Agustinova, D. E. (2013). Latar Belakang dan Masa Depan Libya Pasca Arab Spring. Jurnal Ilmu-Ilmu Sosial, Volume 10 Nomor 2, 120-128.

Akbar, N. A. (2015). Mewaspadai Pembajakan Operasi Perdamaian: Telaah Kritis Intervensi Asing Dalam Konflik Libya. Indonesian Journal of International Studies (IJIS), Volume 2, Nomor 1, 23-36.

Ardiansyah, A. (2014). Libya Pasca Revolusi Kepemimpinan Muammar Al Qaddafi. Skripsi tidak diterbitkan. Jakarta: Program Sarjana Universitas Indonesia. Retrived from http://lib.ui.ac.id/ file?file $=$ digital $/ 20368986-\mathrm{MK}-$ Arif\%20Ardiansyah.pdf

Astrika, L. (2015). Psikologi Politik Konflik dan Keamanan Internasional. Retrived from https://slideplayer.info/ slide/2569383/
Brahm, E. (2003). Conflict Stages. (Online), Retrieved from https:// www.beyondintractability.org/ essay/conflict_stages on April 8, 2020

Fajamugraha. (2011). “30.000 Orang Tewas dalam Perang Libya”. (Online), Retrived from https:// new s.okezone. com $/ \mathrm{read} / 2011 / 09 / 08 / 412 / 500$ 409/30 - 000 - orang-tewas dalam-perang-libya on $15 \mathrm{Juli}$ 2019

Fakih, M. (1991). "NGOs in Indonesia”. (Online), Retrieved from https://scholarworks. umass.edu/cgi/viewcontent. cgi article $=1001 \&$ context $=$ cie ngo on 16 Juli 2019

Fakih, M. (2004). Mayarakat Sipil Untuk Transformasi Sosial Pergolakan Ideologi LSM Indonesia. yogyakarta: Pustaka Pelajar.

Ghafur, M. F. (2014). Agama dan Demokrasi: Munculnya Kekuatan Politik Islam di Tunisia, Mesir, dan Libya. Jurnal Penelitian Politik, Volume 11, Nomor 2, 85-100.

Gunawan, R. (2014). "Muammar Khadafi Tewas dalam Kepungan Pasukan Oposisi”. (Online), Retrived from https://www. liputan 6 .com/global/ 
read/2120214/20-10-2011muammar-khadafi-tewasdalam-kepungan-pasukanoposisi?related =dable\&utm_ expid=.9Z4i5ypGQeGiS7w9a rwTvQ.1\&utm_referrer $=$ https $\% 3 \mathrm{~A} \% 2 \mathrm{~F} \% 2 \mathrm{Fwww}$. google.com $\% 2 \mathrm{~F}$ on 15 Juli 2019

I Gede Adhi Supradnyana, I. D. (2020). Status Tentara Anak dalam Konflik Bersenjata. Kertha Negara, Volume 3, Nomor 3, 1-5.

ICRC. (1996). "ICRC Answer to Your Question”. (Online), Retrieved from https://www. icrc.org/en/publication/0703international-humanitarianlaw-answers-your-questions on 15 Juli 2019.

ICRC. (2005). "Mengenal Lebih jauh Gerakan Palang Merah dan Bulan Sabit Merah Internasional". Jakarta.

ICRC. (2011). "Air Bersih Bagi 100.000 Pengungsi di Tunisia". (Online), Retrived from https:// blogs.icrc.org/indonesia/ air-bersih-bagi - 100-000pengungsi-di-tunisia/ on 17 Juli 2019.

ICRC. (2011). "Kapal Sewaan ICRC Menyatukan Keluarga yang Terpisah di Libya”. (Online), Retrived from https://blogs.icrc. org/indonesia/kapal-sewaanicrc-menyatukan-keluargayang-terpisah-di-libya/ on 17 Juli 2019

ICRC. (2011). "Libya: 6.000 Tahanan Dikunjungi di Tripoli dan Sekitarnya”. (Online), Retrived from https://blogs.icrc. org/indonesia/libya-6-000tahanan-dikunjungi-di-tripolidan-sekitarnya/ on 17 Juli 2019

ICRC. (2011). "Libya: Bantuan Bagi 10.000 Orang Dekat Sirte”. (Online), Retrived from https:// blogs.icrc.org/indonesia/libyabantuan-bagi-10-000-orangdekat-sirte/ on 17 Juli 2019.

ICRC. (2011). "Libya: ICRC Pasok Bantuan Keperluan Medis Terpenting ke Rumah Sakit Sirte”. (Online), Retrived from https://blogs.icrc.org/ indonesia/libya-icrc-pasokbantuan-keperluan-medisterpenting-ke-rumah-sakitsirte/ on 17 Juli 2019.

ICRC. (2011). "Libya: Pasien Dievakuasi dari Rumah Sakit Sirte". (Online), Retrived from https:// blogs.icrc.org/indonesia/libyapasien-dievakuasi-dari-rumahsakit-sirte/ on 17 Juli 2019.

ICRC. (2012). "Angkatan Bersenjata Libya dan ICRC Menandatangani Nota Kesepahaman". 
(Online), Retrived from https:// blogs.icrc.org/indonesia/ angkatan-bersenjata-libya-danicrc-menandatangani-notakesepahaman/ on 17 Juli 2019.

ICRC. (2012). “ICRC Kecam Serangan Terhadap Staf ICRC di Libya”. (Online), Retrived from https://blogs.icrc. org/indonesia/icrc-kecamserangan-terhadap-staf-icrcdi-libya/ on 17 Juli 2019.

ICRC. (2012). "Laporan Tahunan 2011 ICRC: Tahun Krisis yang Kompleks dan Tak Terduga”. (Online), Retrived from https:// blogs.icrc.org/indonesia/ laporan-tahunan-2011-icrctahun-krisis-yang-kompleksdan-tak-terduga/ on 17 Juli 2019.

ICRC. (2012). "Libya: Membantu Identifikasi Jenasah Kuburan Massal". (Online), Retrived from https://blogs.icrc.org/ indonesia/libya-membantuidentifikasi-jenasah-kuburanmassal/ on 17 Juli 2019.

ICRC. (2019). "Sejarah". (Online), Retrived from https://blogs. icrc.org/indonesia/tentangicrc/sejarah/ on 17 Juli 2019.

Karmila, K. E. (2018). Peran United Nations International Children's Emergency Fund (UNICEF) Dalam Menangani
Tentara Anak di Ukraina. eJurnal HI FISIP Universitas Mulawarman, Volume 6, Nomor 4, 1855-1870.

Lewis, D. (2007). The Management of Non-Governmental Development Organizations, 2nd eds. London: Routledge.

Malahayati. (2015). Hukum Organisasi Internasional Sejarah dan Perkembangannya". Retrived from Repository Unimal: http://repository. unimal.ac.id/2154/1/ O R G A N I S A S I \% 20 INTERNASIONAL.pdf

Nainggolan, P. P. (2019). Perang Saudara Serta Prospek Libya dan 'The Arab Spring'. Kajian Singkat Terhadap Isu Aktual dan Strategis.

Ningrum, A. K. (2010). Advokasi Walhi DIY terhadap Korban Bencana Yogyakarta Selama Tahun 2006-2008 . Doctoral dissertation, UAJY, 10.

Nur, M. (2015). “Apa Maksud Resolusi DK PBB 1973 untuk Libya? hanya Tuhan yang Tahu". (Online), Retrived from https: //www.kompasiana.com/ muhammadnur_se/ 5500 9bd9a33311e0725117a7/apamaksud-resolusi-dk-pbb-1973- 
untuk-lybia-hanya-tuhanyang-tahu on 17th July 2019.

Perdana, A. V. (2018). “Direkrut Jadi Tentara, 500.000 Anak-anak Libya Terancam". (Online), Retrived from https:// internasional.kompas.com/ $\mathrm{read} / 2018 / 09 / 26 / 17595831 /$ direkrut-jadi-tentara-500000anak-anak-libya-terancambahaya on 16th July 2019.

Perdana, A. V. (2019). "Korban Jiwa Capai 1.000 Orang, PBB Desak Gencatan Senjata di Libya". (Online), Retrived from https:// internasional.kompas.com/ $\mathrm{read} / 2019 / 07 / 06 / 14531961 /$ korban-jiwa-capai-1000-orangpbb-desak-gencatan-senjatadi-libya on 16th July 2019.

Sahide, A. (2015). The Arab Spring: Membaca Kronologi dan Faktor Penyebabnya. Jurnal Hubungan Internasional, Volume 4, Nomor 2, 118-129.

Sofiyati, P. (2011). Konflik Dan Stress: makalah Pengembangan Dan Perilaku organisasi. Malang: Universitas Brawijaya. Sotopo, H. (2012). Perilaku Organisasi Teori dan Praktik di Bidnag Pendidikan. Bandung: Rosda dan UNM.

Sugito. (2016). Organisasi Internasional: Aktor dan Instrumen dalam Hubungan Internasional. Yogyakarta: Phinisi Pers.

Syahputra, A. B. (2017). Studi Tentang Masa Transisi Libya Pasca Era Khadafi (20112014). Skripsi tidak diterbitkan. Yogyakarta: Program Sarjana Universitas Negeri Yogyakarta. Retrived from http://journal. student.uny.ac.id/ojs/ index.php/risalah/article/ download/9484/9135

Tujil, P. V. (1999). NGOs and Human rights: sources of justice and Democracy. Journal of International Affairs, Volume 52, Nomor 2, 493-512.

Winardi. (1994). Manajemen Konflik: Konflik Perubahan dan Pengembangan. Bandung: Mandar Maju. 